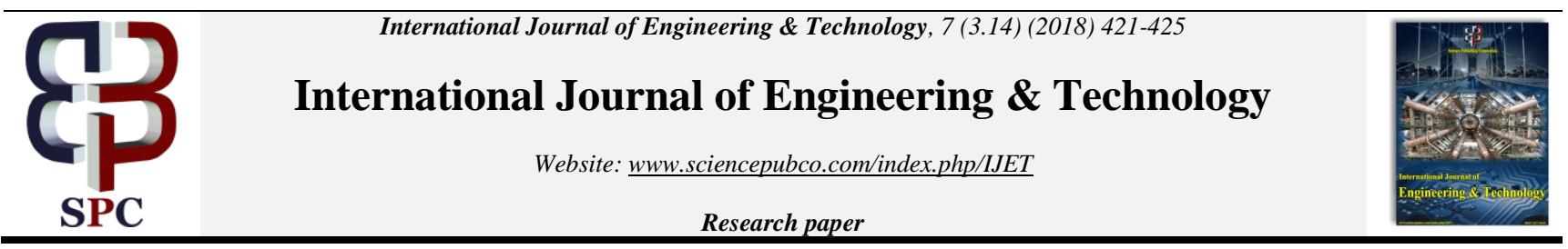

\title{
Modern Media Design: the Impact of Digital Technology on the Development of Regional Publications
} \author{
Mihajlovna Shadrina4, Tatjana Vjacheslavovna Ashutova5 \\ 1Saint Petersburg University of the Humanities and Social Sciences, \\ Fuchika St., 15, Saint-Petersburg, 192238, Russia \\ 2Murmansk Arctic State University, \\ Captain Egorov St., 15, Murmansk, 183038, Russia \\ 3 Murmansk Arctic State University, \\ Captain Egorov St., 15, Murmansk, 183038, Russia \\ 4Murmansk Arctic State University, \\ Captain Egorov St., 15, Murmansk, 183038, Russia \\ 5Murmansk Arctic State University, \\ Captain Egorov St., 15, Murmansk, 183038, Russia
}

Irina Anatoljevna Sukhotina1, Olga Nikolaevna Ivanishcheva2, Anasstasija Vjacheslavovna Koreneva3, Irina

\begin{abstract}
The article examines the principal laws of print design, such as communicativeness, usability and visual attractiveness, in terms of their current use in a modern urban regional newspaper. This paper also presents an analysis of "The Evening Murmansk" newspaper design (logo, photos, front page), along with experts' interviews and readers' polls. The relevance of the work is the unique regional material, as well as a special view on the regional media fate, presented by the perception that modern urban regional newspapers are understaffed with both technical and human resources to attract attention of readers, especially of young people.
\end{abstract}

Keywords: media design, visualization, modern urban regional newspaper.

\section{Introduction}

The relevance of this work derives from the fact that with the advent of computer technology in the modern world, the design of printed publications has changed [2,5,6,7,12]. New opportunities for desktop publishing today allow using in the creation of print media such techniques that one could only dream about. A huge number of typefaces' marks of all possible forms and numerous decorative elements, absence of technical limitations regarding dimensional characteristics of columns, illustrations and size - al this gives a total freedom to creative imagination. Such techniques as L-shaped layout of the material, different column height, negative leading in headings and others are no longer prohibited. A well-known web designer Artemy Lebedev already states that there are no laws in design, and there won't be any in the future. However, any kind of design, be it jewelry, automotive, landscape or media, is to be studied specifically. Unfortunately, today anyone who has a technically mastered graphical package of desktop publishing software starts considering oneself a printing designer. For this reason, there are so many examples of amateur, selfgenerated newspapers and magazines that do not meet any canons of a professional journalist product.

The purpose of this article is to analyze the current state of urban regional press, while identifying its conformity/inconsistency with contemporary requirements of media design.

\section{Methods}

The following methods were used in the study: expert interview, social survey, method of continuous sampling.

\section{Results}

Introduction and overview: statement of the problem Despite the skeptical attitude to existence of laws in the modern media design, it is necessary to recognize the existence of the following three laws: the communicativeness law, the law of usability, the law of visual attractiveness $[9,19]$.

Communicativeness law

Hardly anyone would deny that content is the key element in any medium. That is why the primary design objective of a journal or a newspaper is to provide relevant content so that the consumerreader could fully appreciate any message he or she receives: easily find the necessary topic, get the required information on the publication in the output data, become sure that the magazine issue is "fresh", not published two years ago, etc. "We can talk about design, but in talk we are trying to deliver something: an idea, a feeling or a message. This transfer is the real purpose of design in general. Design is impossible without the transfer of something. The task is to indicate the idea of the transmitted message. Next begins the design itself, that is, the choice of visual 
solutions that you implement to open this message. Design may blur and smear a message, but it can also make it memorable and clear" [19].

\subsection{Usability Law}

It is a well-known fact that humans are inherently lazy. Therefore, they are most likely to miss even the most interesting information, most nicely served proposal, which they might be interested in, if it is uncomfortable, hard, requires a great deal of time and effort to fully capture the meaning.

Here is just a small list of the most common mistakes in presentation of content that interfere with its complete perception

too short, or, conversely, too long line. The minimum line length is 27 characters, the optimal length is 40 and the maximum length is 70 characters;

light small size font against a dark background. This error is most noticeable in full color editions, since any underlay most often consists of all four colors of the SMYK printing palette, and this, when printed, entails the inability to achieve absolute accuracy of combination of printing plates and, therefore, the appearance of colored halos around small light letters;

large text blocks typed in italics or in capital letters. Studies show that italics and capital letters slow the reading speed by $10 \%$;

large number of different font sets. This error, aside from giving an eclectic look to the publication, often misleads the reader - the use of different font sets in the body-text of a newspapermagazine materials disorientates the reader, forcing him/her to guess: whether this is editorial material or indirect advertising;

lack of whitespace. The desire to use every millimeter of a newspaper-magazine space, fear of "air" lead to the fact that newspaper and magazine pages "do not breathe", and the reader's eyes quickly get tired;

mismatch between line spacing and font size. This is considered an error only for the main text, which is comfortably perceived when the line spacing is two points greater than the font size; in the headlines a negative line spacing is acceptable if, of course, it is applied in a design-wise way;

no auto indentation. It is a trendy tip, but, unfortunately, often illiterately used - it looks good only with a set of banners (but not when using text formatting) with obligatory line breaks;

narrow intercolumns. The desire to use vertical rulers in intercolumns without increasing the width of the latter also leads to "airless" space on the line;

pretentiously broken layout, forcing the reader to search for continuation of the text. Broken layout is the most visually attractive type of content presentation, but at the same time most difficult in implementation: the slightest disruption of composite construction of materials will lead to chaos in the line, confuse the reader.

This list of designer techniques that are inconvenient for the reader can be continued since they are verified by time and experience. The use of color printing possibilities also leads to numerous mistakes: inconsistency of colors, multicolor gradient fills, use of inappropriate color models, use of incorrect correlation of warm and cold colors, etc.

If the designer has managed to consider in his or her work all the requirements of the two laws described above, he or she has absolute freedom in the performance of the beloved third law.

\subsection{Visual Attractiveness Law}

How can regional print media attract readers' attention? Readers can easily find beautiful illustrations, as well as any other content, on the Internet.
The best examples of professionally designed media attract readers with a well-thought consistent visual appearance. A professionally built composition of the publication does not only prevent it from breaking into separate fragments, but also creates a memorable visual image in the reader's mind. There are many techniques that allow creating a memorable visual image of a printed publication, such as contrasts, style, suddenness.

When you need to attract attention, the indistinguishable design is not enough, you need to add contrasts: of size (a full-page text paragraph with an illustration in the size of the paragraph with the rest of the space filled with "air"); colors (one color illustration on a black and white page - as a single burst of color); forms (combination of amorphous, blurred background and sharp foreground objects); fonts (massive chopped fonts next to elegant serif ones, scaling of particular font characters); meanings (deliberate violation of the usual order of things, use of knowingly impossible relations); dynamics and statics (a fast moving object on a fixed background, a hurried patter of information kit next to an analytical thoughtful article); habitual and unexpected. "Comparable elements, without violating the laws of integrity, combination and comparison, should be contrast, conflictual to one another, emphasizing, highlighting the range of differences and diversity and each other, and their relationship" [9].

The choice of proper publishing design is the key to success in achieving the individuality of the media: standard style is conservative, calm and boring; corporate style - clear, organized and predictable, creating an impression of trust and reliability; "zesty" style is characterized by the use of vivid images, dazzling design techniques, which makes it effective in a wide range of publications (from conservative, restrained to anarchic and youth-led); information-rich style makes a formal, professional impression; "assorted" style is liberal, easy, creating a bright array of images, provided with a separate text annotation; fontography implies careful work with fonts, which can successfully replace graphic images under the condition of skillful processing and logical transformation of characters; trendy style follows fashion trends, it looks modern or technological, always in trend.

The method of unexpectedness is often used in advertising design; however, it is much more difficult to use it for creation of an image of a printed edition. Instead of an obvious photo, the text is illustrated by nonstandard infographics; bolding of the principal idea in the text is replaced by an unusually formed marginal headings or an insert on a colored underlay. Among the standard-width columns, a "floating" column suddenly appears, with the signature to a photo or a message with important information from the main text; the two-line headline is given in a thick gray chopped and thin black font with serifs and negative leading; two symmetrically blocky materials, representing different points of view, are transformed into L-shaped text blocks entering one another, as in a puzzle. Properly applied height difference of columns creates a geometric outline of the material, makes it slightly more frivolous, but, at the same time, more attractive.

Both a beginner and an experienced designer are always helped by their "breadth of vision": having seen a million paintings, you will start to understand the fine art - therefore, the more different design patterns you know, the more interesting, more original appearance of a publication you'll be able to create.

It is clear that to be successful, a publication must meet a number of criteria, including the ability to quickly perceive information, the presence of a whole and recognizable visual appearance $[4,13,15,18]$, which makes the newspaper an edition with its own "face" [1]; readability of the newspaper [11]. Yet another important feature in the field of printed design is the so-called "compactification" [16]. Studies of foreign scientists have recently turned to the problem of visualization as a basis for perceiving political events, in particular terrorism $[3,10]$. 
In this regard, it is important to see how regional publications meet modern requirements for media design $[8,20]$.

\section{Discussion}

Having considered the features of artistic design of the Murmansk Region city newspaper ("The Evening Murmansk"/ "Vecherniy Murmansk"), the authors identified the major design issues of a regional printed publication.

"The Evening Murmansk" newspaper presents itself as a local daily information and analytical publication intended for the general public. According to the newspaper's employees, the target audience of the newspaper is women aged 28 and over and men aged 35 and over.

The main purpose of the newspaper is to inform citizens about the most important events in the city and to provide a review of these events. Thematically, the newspaper refers to socio-political publications and is one of the main newspapers in the city of Murmansk. It is worth noticing that the newspaper is distributed not only in the territory of the city of Murmansk itself, but also in other 49 cities and towns of the Murmansk Region.

The newspaper has been published since January 2, 1991 and is one of the most authoritative and promising periodicals in the Murmansk Region. It occupies its own niche and is one of the leaders in the printed information market in the Murmansk Region.

To analyze the use of key design elements in the newspaper, we have interviewed a few experts. Executive Secretary of "The Evening Murmansk" newspaper Elena Muracheva told us about the highlights of creating a newspaper issue. Dmitry Baulin, Head of the Marketing Department of the Moscow Research Institute of Applied Chemistry, answered our questions from the standpoint of the newspaper attractiveness to the readers and commented on the results of a sociological survey conducted within the framework of this study. The choice of an expert is because previously Dmitry Baulin worked in the field of website design, and currently writes articles on the activities of the company. Igor Moiseev, a young and promising web designer from the well-known Murmansk portal "vmurmanske.ru", who is also promoting his personal projects ("CesarArts"), has analyzed the design elements of the newspaper in terms of originality and design sophistication.

The analysis of the journalistic material has shown that "The Evening Murmansk" is characterized by consistency of the headings - one of the indispensable qualities of a professional newspaper. This newspaper, as well as most other regional newspapers, is characterized by a "billboard-looking" front page, which essentially turns it into a cover with several announcements of materials from the internal pages of the newspaper along with small news clips. The newspaper is characterized by a mosaic structure of the last page, due to the reference information, advertising modules and congratulations published there. The internal pages of the newspaper are more "serene" in composition.

The header of "The Evening Murmansk" newspaper spreads to the width of the entire front page. It includes the logo, the name of the newspaper, the emblem of the city of Murmansk, as well as the data on periodicity of the newspaper (daily city newspaper), the serial number of the issue, the date of publication of this issue and the date of publication of the first issue of the newspaper.

The newspaper's logo was designed by the newspaper editor. Before the rebranding, which happened in 2010, the logo was a cat carrying a newspaper in his paws. According to Elena Muracheva, the Executive Secretary of "The Evening Murmansk", the logo was not related to the name of the newspaper, although it was associated with it. At a meeting of the editorial board, it was de- cided that the logo should be related to the newspaper; therefore, it is now an abbreviation of its name - a dark blue "B" (in Russian) letter and a white "M" (in Russian) letter. This logo is an example of typographics. As is known, typographics in a newspaper can manifest itself not only in the choice of a font for processing text material, but also as visual elements. Thus, the logo of "The Evening Murmansk" newspaper consists of two letters created with the help of an accredited font, which is inappropriate to use for the main text, but which is suitable for a logo. The logo of the newspaper is also an artistic image, since the letter "B" resembles a sail of a ship, and the letter "M" bears a resemblance to a gull. The presence of such a visual image allows attributing the logo of "The Evening Murmansk" newspaper to typographics.

The marketer Dmitry Baulin called the logo "frivolous, to put it bluntly - inappropriate to the name of the newspaper". He thinks that the chopped font of the newspaper title suggests a logo in more rigid straight lines, "conveying solidity and completeness". In his opinion, the name "Evening Murmansk" is associated with such concepts as the "end of the day" and "debriefing".

We asked the designer Igor Moiseev to comment on the logo of the newspaper from the perspective of its modernity, originality, attractiveness and technical performance. According to the designer, the logo "has become obsolete for ten years". He also notes that the idea to make the letter "B" look like a sail and "M" like a seagull is good, but the performance does not correspond to the status of a quality modern newspaper. The designer believes that the logo contains unpleasant twists and gaps. According to Igor Valerievich, the most "unpleasant" point of the logo is the connection of two lines on the wing of the letter "M", resembling a seagull. From the point of technical execution, the designer called this work unprofessional, "a student's work in the vector". He noted that the logo consists only of the Bezier lines with little attention paid to the details. Moreover, according to Igor Moiseev, the logo does not match the name of the newspaper. "Evening and Murmansk are familiar features of buildings in the sunset, that is, clear outlines and silhouettes. A seagull and a sailboat would probably be more suitable for a newspaper with the name "Maritime Bulletin".

The illustrations in the newspaper are mainly photographic, mostly with people in the picture. Of the 15 analyzed issues, each of them had a picture with people on the front page. Of the 199 pictures presented in the sample, 141 photographs focus on people. Pictures are present on each page, with 3-6 pictures on the spread (both vertical and horizontal). According to Elena Muracheva, the Executive Secretary of "The Evening Murmansk", journalists often bring only horizontal images, while the layout often lacks "vertical" photos. In this case, we have to cut horizontal images or try to rearrange the page layout.

A survey of the audience of the newspaper showed that most respondents did not consider its design very successful. This means that if the competition increases, the newspaper may lose some of its readers. The prospects for development of the printing market in the city of Murmansk and the Murmansk Region do not seem unambiguous. On the one hand, the region's population is constantly shrinking, and the prospects for development of media business are few. On the other hand, the emergence of new industrial enterprises and associations, the strengthening of the Murmansk transport hub, practical steps in the development of Arctic shelf oil and gas reserves, the prospects for creating economic zones in the region may require new specialized or publicly available publications. For this reason, the readers who are indifferent to the design of "The Evening Murmansk" newspaper need to be persuaded with the help of rebranding.

To give the newspaper an individual image, the authors propose a number of recommendations based on analysis of the theoretical material, expert opinions and readers' poll. 
Thus, the editorial staff of the newspaper needs to conduct a largescale study of public opinion on the issue of the newspaper design. Based on the research, the newspaper needs to launch a contest among the readers of the newspaper in order to develop options for the newspaper decoration. The next stage should be a focus group, which will show the editorial office in which direction it is necessary to move when updating the design.

We propose to increase the number of pages in the weekly issues of the newspaper due to the increase in the size of photographs, the total area of free space on the band, the increase in the font size of the headlines and the increase in the area allocated for advertising modules.

The authors of this study recommend "The Evening Murmansk" newspaper to use modern design elements, evolved as a result of the newspaper design transformation. Pages of the newspaper will acquire brightness and individuality due to the use of such an element as infographics [14]. Yet, it is necessary to redesign the newspaper $[16,17,18]$.

\section{Conclusion}

Compliance with the laws of communication, usability and attractiveness required for any media in the modern digital age is closely related to capabilities of the regional media, both technical and human. Unfortunately, a regional city newspaper often does not have such opportunities.

Such a situation somewhat changes the angle of the traditional perception of the city newspaper by its readers and founders. It is believed that modern city newspapers hold a strong position in the information space of the city and form a special publication system, combined by the main categorical feature - their local character (distribution area). However, the functioning of this type of publications is greatly influenced by the founding staff and established relationships with the local authorities, which makes the urban press less pluralistic in terms of ideological and political parameters. The concept of "proximity to the reader", which consists in a gradation of importance of the news on four main criteria: spatial, temporal, social and emotional, is already losing its relevance due to the global information space.

Communication with the regional media leaders showed some illusory nature of their views. Thus, the editors of the regional newspapers quite optimistically assess the situation in terms of competition between printed and audiovisual media. The interview with the Chief Editor of the newspaper "Monchegorsk Worker" Olga Belova, taken March 15, 2010, revealed that the journalist recognized the impact of the "Monchegorsk Television" on such newspaper features as frequency and circulation, but did not consider it a negative influence. Olga Belova understands that television and newspapers often talk about the same news but sees several reasons why the appearance of "Monchegorsk Television" does not detract the significance of the "Monchegorsk Worker" newspaper in the city. First, as a rule, stories for television and materials for the newspaper are prepared by different people. Therefore, presentation of information will be different. Sometimes it is interesting to compare which information is accented by one correspondent and another. Secondly, "Monchegorsk Television" is a cable channel, which is not available in every house; therefore, the editorial staff of the "Monchegorsk Worker" does not need to give up on the newspaper. Thirdly, many Monchegorsk citizens do not trust the news on television, including the regional ones, so they prefer to read about the city news from the newspaper. Olga Belova says that "Monchegorsk TV" only contributes to promotion of the newspaper's circulation, since it often refers to the newspaper materials, recommending the viewer to "read the details in the "Monchegorsk Worker" newspaper at a specific date and issue.
It seems that such a state of affairs is rather an ideal situation than a basic trend. But in small cities, where only a cable channel informs on the local events, such an opportunity for regional press cannot be ruled out.

Nevertheless, the reader gradually departs from the regional newspapers. Reducing circulation is an important indicator of the lack of demand for regional press. In this regard, the situation in the Murmansk Region is very much the same as in other regions. Over the 20 years from 1991 to 2011, the "Murmansk Bulletin" newspaper has decreased its circulation by $85 \%$ (from 40,000 to 6,000 copies). "The Evening Murmansk" newspaper has reduced its circulation from 1995 to 2011 by $80 \%$ (from 30,000 to 5,811 copies).

"The Evening Murmansk" newspaper still tries to create a sense of a unified community of people living in the same city, who do not neglect problems of every resident of the city. The newspaper really reminds the interlocutor, the neighbor, who unobtrusively tells the news without excessive officiality. However, the effect is just the reverse. The style of the newspaper is so transparent that this attitude towards the reader as a friend has made the newspaper popular among the retirees who learn all the news from the newspaper, learn about celebrities, etc. Such a positioning of the newspaper does not attract young reader.

Thus, it can be argued that the development trends of the regional newspaper correspond to the mentality of its readers, though of a certain age, those who had formed their understanding of the region in the Soviet era and live with outdated ideas about the north. Such readers can be attracted to modern design of the newspaper only at a stretch.

\section{References}

[1] A.V. Asmus, Teoreticheskie kontseptsii brenda massovoi gazety [Theoretical Concepts of a Printed Media Brand]. Vestnik Moskovskogo universiteta. Ser. 10. Zhurnalistika, 3, 2009, 39-45.

A. Benckert van de Boel, Designing the Future of the Newspaper. Thesis Project Interaction Design Master at K3, Malmö University, Sweden, 2011, 85. Available online: https://muep.mau.se/

[2] D. Berkowits, Solidarity Through the Visual: Healing Images in the Brussels Terrorism Attacks. Mass Communication and Society, 1(6), 2017. Available online: https://doi.org/10.1080/15205436.2017.1306748

[3] S.V. Fedorova, Vizualizatsiya kak vedushchaya tendentsiya razvitiya SMI [Visualization as a Leading Trend in Media Development]. Filologicheskie nauki. Voprosy teorii i praktiki, 7(37), 2014, 189191.

[4] S.B. Golovko, Novaya epokha gazetnogo dizaina [New Era of the Newspaper Design]. Vestnik elektronnykh i pechatnykh SMI, 21, 2014, 51-77.

[5] S.B. Golovko, Dizain rossiiskikh gazet: genezis, sovremennoe sostoyanie i tendentsii razvitiya: [Russian Newspapers Design: Genesis, Current State and Development Trends]. Moscow, 2011, 28.

[6] M.J. Haught, The New Newspaper: Examining the Role of Design in the Modern Print Edition. A thesis submitted to the Graduate College of Marshall University. Marshall University, 93, 2010. Available online: http://mds.marshall.edu/cgi/viewcontent.cgi?article=1078\&context $=$ etd

[7] K. Holmquist, C. Wartenberg, The Role of Local Design Factors for Newspaper Reading Behavior - an Eye-Tracking Perspective. Lund University Cognitive Studies, 127, 2005. Available online: http://www.lucs.lu.se/LUCS/127/LUCS.127.pdf

[8] G.A. Knabe, Entsiklopediya dizainera pechatnoi produktsii. Professionalnaya rabota [Printed Media Design Encyclopedia. Professional Work]. Moscow: Williams, 2006, 736.

[9] M. Mortensen, Struggles for Visibility. Surveillance Representations and Self-Representations of Terrorists in the News Media. Journalism Studies, 2018. Available online: https://doi.org/10.1080/1461670X.2018.1464403

[10] L.A. Orlova, Vliyanie klipovogo myshleniya na gazetnyi dizain. Udobochitaemost - vershina gazetnogo dizaina [The Influence of 
Clip Thinking on Newspaper Design. Readability as the Top of the Newspaper Design]. Mediasreda, 12, 2017, 213-219.

[11] A.S. Sundukov, Dizain rossiiskikh zhurnalov: istoriya, teoriya, praktika [Russian Magazines Design: History, Theory, Practice]. Voronezh, 2011, 24

[12] A.L. Svitich, Graficheskaya illyustratsiya kak vizualnyi komponent kontenta kachestvennykh [Specifics of Graphic Illustrations as a Content Component of Quality Publications]. Moscow, 2016, 27.

[13] E.M. Tikhonova, Infografika $\mathrm{v}$ arsenale zhurnalista sovremenno rossiiskoi regionalnoi gazety [Infographics in the Arsenal of a Journalist of the Modern Russian Regional Newspaper]. Vestnik Tomskogo gosudarstvennogo universiteta, 2(14), 2011, 145-152.

[14] A.V. Tsvetkova, Dizain zhurnalov v kontekste novykh khudozhestvennykh praktik XX veka: [Magazines' Design in the Context of New Artistic Practices of the Twentieth Century]. Moscow, 2016, 27.

[15] A.Y. Tyshetskaya, Sovremennyi gazetnyi redizain: k opredeleniyu ponyatiya [Modern Newspaper Redesign: To the Definition of the Concept]. Vestnik Tomskogo gosudarstvennogo universiteta, 2(6), 2009, 109-115.

[16] A.Y. Tyshetskaya, Dizain sovremennoi gazety i novye podkhody k formirovaniyu ee soderzhaniya [Modern Newspaper Design and New Approaches to Formation of Its Content]. Vestnik Tomskogo gosudarstvennogo universiteta, 2(18), 2012, 130-138.

[17] V.V. Volkova, Spetsifika mediadizaina [Media Design Specifics] Vestnik Moskovskogo universiteta. Ser. 10. Zhurnalistika, 4, 2014, 5-21.

[18] R. Williams, J. Tollet, Studiya dizaina Robin Vilyams [Robin Williams Design Workshop] St. Petersburg: Simvol-Plyus. 2008, 280.

[19] S.B. Yufkina, K.A. Loginova, N.M. Frolova, Dizain regionalnykh pechatnykh SMI kak uslovie ikh uspeshnogo funktsionirovaniya [Regional Print Media Design as a Prerequisite for Successful Functioning]. Mediaissledovaniya, 4-1, 2017, 198-201. 